\title{
Evaluation of Serum Gamma-Glutamyl Transferase Activity and Serum Uric Acid Level in Type II Diabetes Mellitus Patients
}

\author{
KM Devi ${ }^{1}$, RK Patil ${ }^{2}$, Mandeep Malhi ${ }^{3}, \mathrm{HC} \mathrm{Patil}^{4}$ \\ ${ }^{1}$ Student, B. Pharmacy, Adesh Institute of Pharmacy and Biomedical Sciences, Bathinda \\ ${ }^{2}$ Professor, Department of Pharmacy Practice, Adesh Institute of Pharmacy and Biomedical Sciences, \\ Bathinda \\ ${ }^{3}$ Lecturer, Department of Pharmaceutics, Adesh Institute of Pharmacy and Biomedical Sciences, \\ Bathinda \\ ${ }^{4}$ Professor \& Principal, Department of Pharmacy Practice, Adesh Institute of Pharmacy and Biomedical \\ Sciences, Bathinda \\ Corresponding Author: RK Patil
}

\begin{abstract}
Studies in past few years have linked oxidative stress as a potential marker of diabetes mellitus. Thus, based on the previous literature this study was planned with the aim to evaluate serum GGT activity and serum uric acid level as potential indicators of oxidative stress in type- 2 diabetes mellitus patients.

A total of 68 participants were included following inclusion and exclusion criteria. After the statistical analysis, statistically significant differences were observed in the mean GGT activity between controls $(30.19 \pm 7.639 \mathrm{IU} / \mathrm{L})$ and cases $(59.386 \pm 22.215 \mathrm{IU} / \mathrm{L})(\mathrm{p}=0.000)$. Similarly, mean serum uric acid level of controls $(5.180 \pm 1.476 \mathrm{mg} / \mathrm{dl})$ and cases $(3.510 \pm 0.792 \mathrm{mg} / \mathrm{dl})(\mathrm{p}=0.000)$, were also statistically difference.

Further, after applying Pearson's correlation, positive correlation between GGT and $\mathrm{HbA}_{1} \mathrm{C}$ level $(\mathrm{r}=0.390)$ and with GGT and FPG level $(\mathrm{r}=0.375)$ were observed. However, correlation between $\mathrm{HbA}_{1} \mathrm{c}$ and uric acid ( $\left.\mathrm{r}=-0.372\right)$; FPG and uric acid $(\mathrm{r}=-0.374)$ level suggested serum uric acid concentration was inversely proportional to the degree of dysglycemia in diabetes mellitus patients of this study.

Hence, results of this study suggested serum GGT activity and serum uric acid level were altered as compared to controls and cases. Thus, further study on these parameters may help to serve it as potential markers of oxidative stress in diabetes mellitus patients.
\end{abstract}

Key Words: Diabetes mellitus, $\mathrm{HbA}_{1} \mathrm{C}$, GGT, Uric acid and Oxidative stress.

\section{INTRODUCTION}

The prevalence of DM is about $6.4 \%$, affecting 285 million adults in 2010 and expected to increase by $7.7 \%$ affecting a million of individuals by $2030^{1}$. Previous studies have suggested, diabetes mellitus to be one of the free radical diseases which propagates severe complications with increased free radical formation and oxidative stress is thought to be increased in system where the rate of free radical production is high and antioxidant mechanisms are impaired ${ }^{2,3}$. Thus, considering the antioxidant activity of glutathione, increased level of serum gamma-glutamyl transferase (GGT) may be linked to oxidative stress because serum gamma- glutamyl transferase (GGT) is an ectoplasmic enzyme responsible for the extracellular catabolism of glutathione and 
GGT have been found to have an important role in glutathione homeostasis ${ }^{4}$. Further, many studies have even suggested a positive association between serum GGT and oxidative stress in the patients of diabetes mellitus 5 .

Similarly, another important observation made in various studies were, uric acid on account of its reducing nature may function as an antioxidant and it has been observed that, serum uric acid level is significantly decreased in chronic diabetes mellitus patients as compared to nondiabetic individuals ${ }^{6}$. However, observation suggested by many different studies were not consisted with GGT and uric acid level. Thus, based on the above observation, present study was directed towards the evaluation of serum GGT activity and serum uric acid level in diabetes mellitus patients as compared to normal individuals.

\section{METHODOLOGY}

\section{Inclusion Criteria:}

As case: Known cases of diabetes mellitus, patients above the age more than 18 years were considered.

As control: Normal healthy individual with no history of diabetes mellitus above the age of 18 years were taken as controls.

\section{Exclusion criteria:}

Patients with known history of infectious disease, autoimmune disease, immune compromised patients, pregnant women and lactating mother were excluded from the study.

Inform written consent was taken from all the participants at the time of enrolment for this study.

\section{STATISTICAL ANALYSIS:}

Mean \pm SD were calculated for all the parameters analyzed and were compared by Student's t-test and correlated by calculating Pearson's correlation coefficient using Microsoft excel. P-values considered significant were as follows:

$\mathrm{P}<0.05-$ As significant

$P<0.001$ - As highly significant

$\mathrm{P}>0.05$ - As non-significant

\section{RESULTS}

This study was a hospital-based survey and based on inclusion and exclusion criteria, participants were selected. A total of 34 type- 2 diabetes mellitus patients and 34 age matched normal individuals were included as controls for this study. The statistical analyses of different parameters are as follows:

Table 1: Comparison of serum gamma glutamyl transferase (GGT) activity between controls and diabetes mellitus patients by Student's t-test.

\begin{tabular}{|l|c|c|c|}
\hline Parameter & $\begin{array}{l}\text { Control groups }(\mathbf{n}=34) \\
\text { Mean } \pm \text { SD }\end{array}$ & $\begin{array}{l}\text { Diabetic patients(n=34) } \\
\text { Mean } \pm \text { SD }\end{array}$ & p- value \\
\hline Serum GGT activity (IU/L) & $30.19 \pm 7.639$ & $59.386 \pm 22.215$ & 0.000 \\
\hline
\end{tabular}

Statistically significant differences were observed between the mean serum GGT activity of controls $(30.19 \pm 7.639 \mathrm{IU} / \mathrm{L})$ and diabetic patients $(59.386 \pm 22.215 \mathrm{IU} / \mathrm{L})(\mathrm{p}=0.000)$.

Table 2 : Comparison of serum uric acid level between controls and diabetic mellitus patients by Student's t-test.

\begin{tabular}{|c|l|l|c|}
\hline Parameter & $\begin{array}{l}\text { Control group }(\mathbf{n}=34) \\
\text { Mean } \pm \text { SD }\end{array}$ & $\begin{array}{l}\text { Diabetic group }(\mathbf{n}=34) \\
\text { Mean } \pm \text { SD }\end{array}$ & p-value \\
\hline Serum Uric acid $(\mathrm{mg} / \mathrm{dl})$ & $5.180 \pm 1.476$ & $3.510 \pm 0.792$ & 0.000 \\
\hline
\end{tabular}

Statistically significant differences were observed in the mean serum uric acid level of controls $(5.180 \pm 1.476 \mathrm{mg} / \mathrm{dl})$ and type 2 diabetic patients $(3.510 \pm 0.792 \mathrm{mg} / \mathrm{dl})$ $(\mathrm{p}=0.000)$.

Graph 1: Representing the differences in the mean $\mathrm{HbA} 1 \mathrm{C}$ and Uric acid level between control and cases.
After the comparison of mean $\mathrm{HbA}_{1} \mathrm{C}$ and uric acid level between control and cases $9.2 \%, 4.9 \%$ and $158.3 \mathrm{mg} / \mathrm{dl}$, $80.1 \mathrm{mg} / \mathrm{dl}$ respectively results suggested a significant difference in mean between control and cases $(p=0.000)$. 


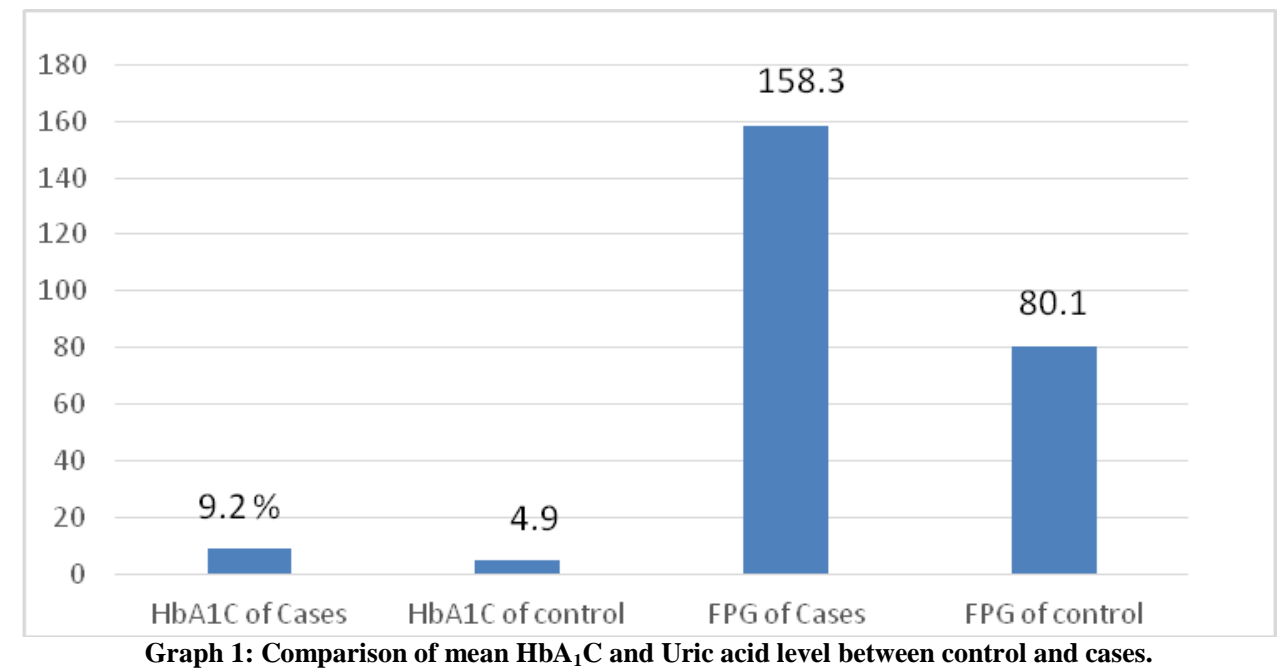

Table 3: Correlation between different parameters. [Pearson's correlation coefficient (r) and p-value].

\begin{tabular}{|l|l|l|}
\hline Clinical Parameters & r-value & p-value \\
\hline GGT $-\mathrm{HbA} A_{1} \mathrm{c}$ & 0.390 & 0.033 \\
\hline Uric acid $-\mathrm{HbA}_{1} \mathrm{c}$ & -0.372 & 0.043 \\
\hline GGT -FPG & 0.375 & 0.041 \\
\hline Uric acid - FPG & -0.374 & 0.042 \\
\hline
\end{tabular}

After applying Pearson's correlation coefficient, it was found that there was a positive correlation between serum GGT activity and HbA1c level ( $\mathrm{r}=0.390)$ and also with serum GGT activity and FPG $(\mathrm{r}=0.375)$.

However, after applying Pearson's correlation coefficient between serum uric acid and HbA1c ( $\mathrm{r}=-0.372)$ and with serum uric acid and FPG level ( $\mathrm{r}=-0.374)$, results suggested negative correlation.

\section{DISCUSSION}

Oxidative stress is considered to be one of the reasons of cellular functional impairment $^{7}$. It is a condition where excessive production of free radicals and reactive oxygen species (ROS), as well as reduced antioxidative properties were seen $^{8}$. Different studies had reported that GGT has a central role in the maintenance of intracellular antioxidant defenses through its mediation of extracellular glutathione transport into most types of cells ${ }^{9}$.Some researchers even consider serum GGT activity as a direct marker for increased oxidative stress $^{10}$. Similarly, previous studies suggested, uric acid is a physiological free radical scavenger ${ }^{11}$.The association between serum GGT activity, serum uric acid and type 2 diabetes mellitus risk have been documented in several previous studies but still a clear diagnostic role has not been well documented. Thus, this study was done with the purpose to evaluate the serum GGT activity and serum uric acid level as potential indicators of oxidative stress in diabetes mellitus.

The findings of this study had demonstrated the mean level of serum GGT activity in this present study was $(59.38 \pm 22.21 \mathrm{IU} / \mathrm{L})$ in cases and $(30.19 \pm 7.63 \mathrm{IU} / \mathrm{L})$ in controls, suggesting significantly higher in cases as compared to age matched normal healthy controls $(\mathrm{p}=0.000)$. This finding was similar to the outcomes of a study by Balogun et al., $2008^{12}$. Another important finding of this study was a positive correlation between serum GGT activity with HbA1c $(r=0.39)$ and FPG $(r=0.375)$ which was similar to the finding of Gohel and Chacko., 2013 ${ }^{13}$. Similar correlations were also observed in a study by Iqbal et al., $2010^{14}$.

On the other hand, mean serum uric acid level in present study was $(3.51 \pm 0.79 \mathrm{mg} / \mathrm{dl})$ in cases and $(5.18 \pm 1.47 \mathrm{mg} / \mathrm{dl})$ in controls respectively suggesting a statistically significant difference $(p=0.000)$. Similar results were obtained in the study by Sharma et al., $2018^{15}$. On the contrary, a study conducted by Lal et al., 2009 found elevated level of serum uric acid in diabetic patients ${ }^{16}$. Furthermore, after applying Pearson's correlation coefficient between serum uric 
acid with HbA1c (r=-0.372) and FPG (r=$0.374)$ show inverse correlation. Which was similar to the result obtained in a study of Austrian men ${ }^{17}$. The significant reduction in serum uric acid concentration in diabetic patients as compared to healthy controls obtained in this present study may be due to the fact that, the higher plasma glucose concentration may increase fractional excretion of urate (soluble form of uric acid in blood) caused by an effect of glucose at the renal tubule ${ }^{18}$.

Thus, the findings of this study in terms of decreased serum uric acid levels and increased serum GGT activity in diabetic patients give us the reason to look for the association between the antioxidant status, with the evolution of diabetes mellitus and its chronic complications.

\section{CONCLUSION}

Diabetes mellitus is undoubtedly one of the most challenging health problems of $21^{\text {st }}$ century. Thus, after the analysis of results, this study suggested that serum GGT activity and serum uric acid levels were altered between controls and cases and it may serve as potential markers of oxidative damage in diabetes mellitus patients.

\section{Acknowledgement: None}

\section{Conflict of Interest: None}

\section{Source of Funding: None}

\section{Ethical Approval: Approved}

\section{REFERENCES}

1. Shaw JE, Sicree RA, Zimmet PZ. Global estimates of the prevalence of diabetes for 2010 and 2030. Diabetes research and clinical practice, 2010; 87(1):4-14.

2. Gawlik K, Naskalski JW, Fedak D, PawlicaGosiewska D, Grudzień U, Dumnicka P, Małecki MT, Solnica B. Markers of antioxidant defense in patients with type 2 diabetes. Oxidative medicine and cellular longevity, 2016.
3. Irshad M, Chaudhuri PS. Oxidantantioxidant system: role and significance in human body. Indian J Exp Biol. 2002 Nov; 40(11): 1233-9.

4. Park H, Lee E, Kim Y, Jung HY, Kim KM, Kwon O. Metabolic Profiling Analysis Reveals the Potential Contribution of Barley Sprouts against Oxidative Stress and Related Liver Cell Damage in Habitual Alcohol Drinkers. Antioxidants, 2021;10(3): 459.

5. Evans JL, Goldfine ID, Maddux BA, Grodsky GM. Are oxidative stressactivated signaling pathways mediators of insulin resistance and $\beta$-cell dysfunction. Diabetes, 2003;52(1):1-8.

6. Zoppini G, Targher G, Chonchol M, Ortalda V, Abaterusso C, Pichiri I, Negri C, Bonora E. Serum uric acid levels and incident chronic kidney disease in patients with type 2 diabetes and preserved kidney function. Diabetes care, 2012;35(1):99-104.

7. Agarwal A, Virk G, Ong C, Du Plessis SS. Effect of oxidative stress on male reproduction. The world journal of men's health, 2014;32(1):1-7.

8. Banerjee A, Das D, Paul R, Roy S, Bhattacharjee A, Prasad SK, Banerjee O, Mukherjee S, Maji BK. Altered composition of high-lipid diet may generate reactive oxygen species by disturbing the balance of antioxidant and free radicals. Journal of basic and clinical physiology and pharmacology, 2020;31(3).

9. Lim JC, Grey AC, Zahraei A, Donaldson PJ. Age-dependent changes in glutathione metabolism pathways in the lens: new insights into therapeutic strategies to prevent cataract formation; a review. Clinical and Experimental Ophthalmology, 2020;48(8):1031-42.

10. Kumar A, Siddiqi NJ, Alrashood ST, Khan HA, Dubey A, Sharma B. Protective effect of eugenol on hepatic inflammation and oxidative stress induced by cadmium in male rats. Biomedicine and Pharmacotherapy, 2021;139.

11. Kurajoh M, Fukumoto S, Yoshida S, Akari S, Murase T, Nakamura T, Ishii H, Yoshida H, Nagata Y, Morioka T, Mori K. Uric acid shown to contribute to increased oxidative stress level independent of xanthine oxidoreductase activity in MedCity21 health examination registry. Scientific Reports, 2021;11(1):1-9. 
12. Balogun WO, Adeleye JO, Akinlade KS, Adedapo KS, Kuti M. Frequent occurrence of high gamma-glutamyl transferase and alanine amino transferase among Nigerian patients with type 2 diabetes. African journal of medicine and medical sciences, 2008;37(2):177-83.

13. Gohel MG, Chacko AN. Serum GGT activity and hsCRP level in patients with type 2 diabetes mellitus with good and poor glycemic control: An evidence linking oxidative stress, inflammation and glycemic control. Journal of Diabetes and Metabolic Disorders, 2013;12(1):1-8.

14. Iqbal A, Iftikhar U, Ali FA, Memon S, Zuberi N. Comparison of gamma glutamyltransferase in normal and in type 2 diabetics. Journal of the Pakistan Medical Association, 2010;60(11):945.

15. Sharma N, Singh NK, Singh OP, Pandey V, Verma PK. Oxidative stress and antioxidant status during transition period in dairy cows. Asian-Australasian Journal of Animal Sciences,2011;24(4):479-84.
16. Lal SS, Sukla Y, Singh A, Andriyas EA, Lall AM. Hyperuricemia, high serum urea and hypoproteinemia are the risk factor for diabetes. Asian journal of medical sciences, 2009;1(2):33-4.

17. Strasak A, Ruttmann E, Brant L, Kelleher C, Klenk J, Concin H, Diem G, Pfeiffer K, Ulmer H, VHM\&PP Study Group. Serum uric acid and risk of cardiovascular mortality: a prospective long-term study of 83683 Austrian men. Clinical chemistry, 2008;54(2):273-84.

18. So A, Thorens B. Uric acid transport and disease. The Journal of clinical investigation, 2010;120(6):1791-9.

How to cite this article: KM Devi, Patil RK, Malhi $M$ et.al. New evaluation of serum gamma-glutamyl transferase activity and serum uric acid level in type II diabetes mellitus patients. Int J Health Sci Res. 2021; 11(9): 187191. DOI: https://doi.org/10.52403/ijhsr. 20210929 